Finanse, Rynki Finansowe, Ubezpieczenia nr 3/2017 (87), cz. 2

DOI: $10.18276 /$ frfu.2017.87/2-13

s. $151-160$

\title{
Struktura kosztów pracy w wybranych krajach Unii Europejskiej
}

\begin{abstract}
Rafal Rosiński*
Streszczenie: $\mathrm{Cel}$ - Analiza struktury kosztów pracy w wybranych krajach Unii Europejskiej oraz możliwość jej porównania w poszczególnych krajach.

Metodologia badania - W części wprowadzającej posłużono się metodą analizy literatury i aktów prawnych, natomiast w części empirycznej zastosowano metodę badania dokumentów - oficjalnych raportów OECD oraz obliczeń własnych autora.

Wynik - Analiza struktury kosztów pracy w wybranych krajach Unii Europejskiej ukazała, że jest ona zróżnicowana w poszczególnych krajach UE i uzależniona od polityki społeczno-gospodarczej danego kraju, tj. od systemu ubezpieczeń społecznych oraz poziomu i konstrukcji podatku dochodowego.

Oryginalność/wartość - przy analizie kosztów pracy należy przede wszystkim zwrócić uwagę na minimalny i przeciętny poziom wynagrodzenia oraz wysokość kosztów pozapłacowych w poszczególnych krajach, gdyż to one głównie decydują o rzeczywistych kosztach pracy ponoszonych przez pracodawcę.
\end{abstract}

Słowa kluczowe: koszty pracy, klin podatkowy, Unia Europejska

\section{Wprowadzenie}

Koszty pracy nieodłącznie związane są z funkcjonowaniem przedsiębiorstwa w gospodarce narodowej. Na koszty pracy składają się zarówno płacowe, jak i pozapłacowe wydatki ponoszone przez pracodawcę w związku z zatrudnieniem pracownika. W świetle porównań międzynarodowych ukazywane są przede wszystkim płacowe elementy kosztów płacy, na które składają się wysokość minimalnego czy przeciętnego wynagrodzenia w gospodarce narodowej oraz wysokość płacowego klina podatkowego (tax wedge), co daje nam obraz całkowitych płacowych kosztów pracy oraz ich struktury. Celem artykułu jest przedstawienie struktury kosztów pracy w wybranych krajach Unii Europejskiej oraz możliwości jej porównania w poszczególnych krajach. Badania wykonano na podstawie oficjalnych raportów OECD oraz obliczeń własnych autora.

\footnotetext{
dr Rafał Rosiński, Politechnika Koszalińska, Wydział Nauk Ekonomicznych, Katedra Finansów, e-mail: rafal. rosinski@tu.koszalin.pl
} 


\section{Koszty pracy a płacowy klin podatkowy}

Koszty pracy to wydatki ponoszone przez jednostkę gospodarczą związane z zatrudnieniem pracownika. W literaturze przedmiotu często zamiennie nazywane są kosztami pracodawcy lub kosztami zatrudnienia i traktowane często jako jeden z czynników składających się na cenę sprzedawanego produktu czy usługi (Triplett, 1983, s. 4). Koszty pracy określane są więc jako wartość pracy wykorzystanej w celu świadczenia usług czy też wytworzenia określonych wyrobów (Makowski, 2000, s, 79). Główny Urząd Statystyczny wskazuje elementy składające się na koszty pracy, zaliczając do nich następujące składniki:

- wynagrodzenia osobowe,

- dodatkowe wynagrodzenia roczne dla pracowników jednostek sfery budżetowej,

- wynagrodzenia z tytułu umowy zlecenia lub umowy o dzieło,

- honoraria,

- wydatki na doskonalenie, kształcenie i przekwalifikowanie kadr,

- wydatki na delegacje służbowe,

- wydatki związane z bezpieczeństwem i higieną pracy,

- składki na ubezpieczenie emerytalne, rentowe i wypadkowe opłacone przez pracodawcę, łącznie ze składkami na Fundusz Gwarantowanych Świadczeń Pracowniczych i składkami na Fundusz Pracy,

- zakładowy fundusz świadczeń socjalnych,

- świadczenia o charakterze rzeczowym,

- pozostałe wydatki przeznaczone m.in. na werbunek, rekrutację i nabór kadr, dojazdy do pracy pracowników, wydatki poniesione przez pracodawcę na ubezpieczenia pracowników w trzecim filarze, jeżeli są wliczane w koszty działalności jednostki sprawozdawczej,

- $\quad$ wypłaty z tytułu udziału w zysku do podziału lub z nadwyżki bilansowej w spółdzielniach (Koszty pracy..., 2012, s. 13-14).

Biorąc pod uwagę ww. składniki pracy, można podzielić je na składniki płacowe, czyli wydatki związane bezpośrednio z wynagrodzeniem pracownika i pozapłacowe elementy (Furmańska-Maruszak, 2013, s. 102). W celu porównań międzynarodowych, Eurostat zawęża koszty pracy, zaliczając do płacowych składników koszty wynagrodzeń i płac a do pozapłacowych składników - płacone przez pracodawcę składki na ubezpieczenie społeczne (Eurostat, 2017).

Z pojęciem kosztów pracy nierozerwalnie związane jest pojęcie płacowego klina podatkowego, które określane jest jako różnica między kosztami pracodawcy wynikającymi z zatrudnienia pracownika a kwotą faktyczną otrzymywaną przez niego - wynagrodzeniem netto (Polarczyk, 2007, s. 1). Porównywanie poziomu płacowego klina podatkowego w krajach jest możliwe dzięki przedstawieniu go w postaci procentowej. Płacowy klin podatkowy w tym przypadku stanowi stosunek różnicy między kosztami pracy a wynagrodzeniem netto (klin podatkowy w ujęciu wartościowym) do łącznych kosztów pracy (Labour taxes..., 2005). Wysokość płacowego klina podatkowego w poszczególnych krajach uzależniona jest od jego struktury, czyli składników wchodzących w jego skład, a także 
od podstawy jego obliczenia. Jako podstawę odniesienia (wymiaru) stosuje się przeważnie poziom przeciętnego wynagrodzenia $\mathrm{w}$ gospodarce $\mathrm{w}$ danym kraju, a dla potrzeb ustalenia wysokości podatku od dochodów osobistych - osobę niebędącą w związku małżeńskim i nieposiadającą dzieci. Taką metodologię ustalania płacowego klina podatkowego stosuje Organizacja Współpracy Gospodarczej i Rozwoju - OECD (Explanatory notes..., 2017).

\section{Analiza kosztów pracy w Polsce}

Do analizy struktury kosztów pracy w Polsce brane pod uwagę będą następujące elementy: podatek dochodowy od osób fizycznych, którego wysokość dla minimalnego i przeciętnego wynagrodzenia kształtuje się w pierwszym progu podatkowym ${ }^{1}$, ubezpieczenia społeczne, tj. ubezpieczenie emerytalne, rentowe, chorobowe oraz wypadkowe ${ }^{2}$, ubezpieczenie zdrowotne ${ }^{3}$, obowiązkowa składka na Fundusz Pracy ${ }^{4}$ i Fundusz Gwarantowanych Świadczeń Pracowniczych ${ }^{5}$ oraz wysokość wynagrodzenia netto.

Biorąc pod uwagę wysokości stawek obowiązujących w 2017 roku i dokonując stosownych obliczeń, można zauważyć, że przy przeciętnym wynagrodzeniu w Polsce w 2017 roku, tj. 4263 zł, najmniejszy udział w kosztach pracy stanowi podatek dochodowy od osób fizycznych. Mimo że nominalna stawka podatku dochodowego od osób fizycznych wynosi $18 \%$, to przy uwzględnieniu ryczałtowych kosztów uzyskania przychodu, kwoty wolnej od podatku, odliczeniu ulg pośrednich od dochodu, tj. składki na ubezpieczenie emerytalne, rentowe i chorobowe oraz odliczenie od podatku części składki ubezpieczenia zdrowotnego, rzeczywista wysokość podatku dochodowego kształtuje się na poziomie 311 zł (por. rys. 1) i stanowi najmniejszą część całkowitych kosztów pracy. Biorąc pod uwagę udział procentowy, stanowią one $6,05 \%$ całkowitych kosztów pracy (por. rys. 2). Kolejnym składnikiem w kosztach pracy są składki na ubezpieczenie zdrowotne, których nominalna stawka wynosi 9\%, a wysokość składki przy przeciętnym wynagrodzeniu kształtuje się na poziomie 331,07 zł, tj. 6,44\% całkowitych kosztów pracy. Łączne składki na ubezpieczenie emerytalne, rentowe i chorobowe pobierane od wynagrodzenia brutto pracownika wynoszą 584,46 zł, czyli 11,37\% całkowitych kosztów pracy. Biorąc pod uwagę powyższe elementy kosztów pracy, wysokość wynagrodzenia netto dla pracownika wynosi 3036,47 zł. Należy oczywiście przy wyliczaniu całkowitych kosztów pracy uwzględnić także elementy pozapłacowe, które ponosi pracodawca poza wynagrodzeniem brutto pracownika, tj. składki na

1 Ustawa z 26 lipca 1991 r. o podatku dochodowym od osób fizycznych (Dz.U. z 2000 r., nr 14, poz. 176 z późn. $\mathrm{zm}$.).

2 Ustawa z 13 października 1998 r. o systemie ubezpieczeń społecznych (Dz.U. z 2008 r., nr 171, poz. 1056).

3 Ustawa z 6 lutego 1997 r. o powszechnym ubezpieczeniu zdrowotnym (Dz.U. z 1997 r., nr 28, poz. 153 z późn. $\mathrm{zm}$.).

4 Ustawa z 20 kwietnia 2004 r. o promocji zatrudnienia i instytucjach rynku pracy (Dz.U. z 2008 r., nr 69 , poz. 415 z późn. zm.)

5 Ustawa z 29 grudnia 1993 r. o ochronie roszczeń pracowniczych w razie niewypłacalności pracodawcy (Dz.U. z 1994 r., nr 1, poz.1, z późn. zm.). 
ubezpieczenie emerytalne $-9,76 \%$ podstawy wymiaru, rentowe $-6,5 \%$ podstawy wymiaru i wypadkowe $-1,8 \%$ podstawy wymiaru oraz składki na Fundusz Pracy $-2,45 \%$ podstawy wymiaru i Fundusz Gwarantowanych Świadczeń Pracowniczych - $0,1 \%$ podstawy wymiaru. Ich łączna wysokość, przy przeciętnym wynagrodzeniu w 2017 roku, kształtuje się na poziomie 584,46 zł, co stanowi 17,09\% całkowitych kosztów pracy. Należy wziąć także pod uwagę to, że w przedstawionych wyliczeniach nie uwzględnia się części obowiązkowych elementów pozapłacowych, dotyczących przedsiębiorców zatrudniających pracowników, które z punktu widzenia prawa zobowiązane są odprowadzać składki na Fundusz Emerytur Pomostowych, Państwowy Fundusz Rehabilitacji Osób Niepełnosprawnych czy Zakładowy Fundusz Świadczeń Socjalnych, które dodatkowo zwiększyłyby poziom pozapłacowych elementów kosztów pracy.

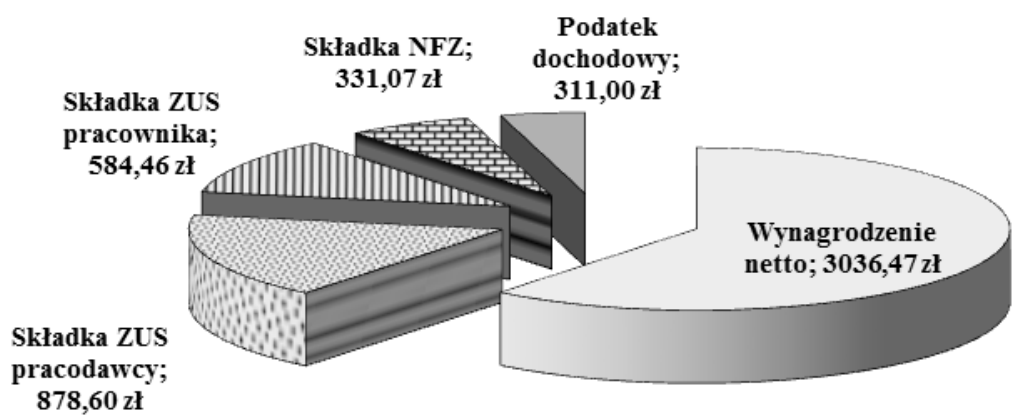

Wynagrodzenie brutto: $4263 \mathrm{zl}$

Koszt pracy: 5141,60 zl

Klin podatkowy - 2105,13 tj. 40,94\% kosztów pracy

Rysunek 1. Struktura kosztów pracy przy przeciętnym wynagrodzeniu w Polsce w 2017 roku Źródło: opracowanie własne.

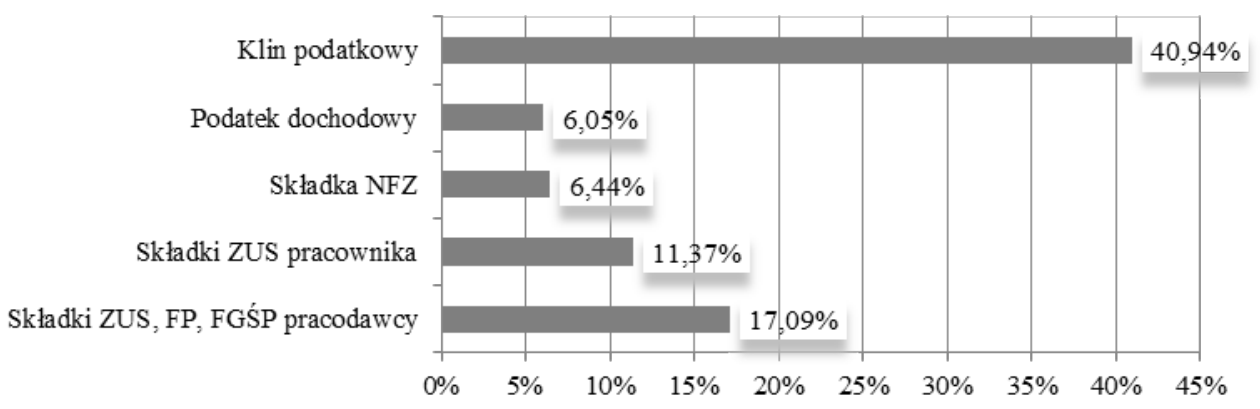

Rysunek 2. Struktura płacowego klina podatkowego przy przeciętnym wynagrodzeniu w Polsce w 2017 roku

Źródło: opracowanie własne. 
Z przedstawionych obliczeń dla przeciętnego wynagrodzenia w Polsce wynika, że klin podatkowy ukształtował się na poziomie 40,94\%. Dla porównania warto dokonać obliczeń jak kształtowałaby się struktura kosztów pracy, biorąc pod uwagę minimalne wynagrodzenie w Polsce, które w 2017 roku wynosi 2000 zł brutto. Na rysunku 3 przedstawiono strukturę kosztów pracy przy minimalnym wynagrodzeniu w Polsce w 2017 roku, natomiast na rysunku 4 - strukturę płacowego klina podatkowego.

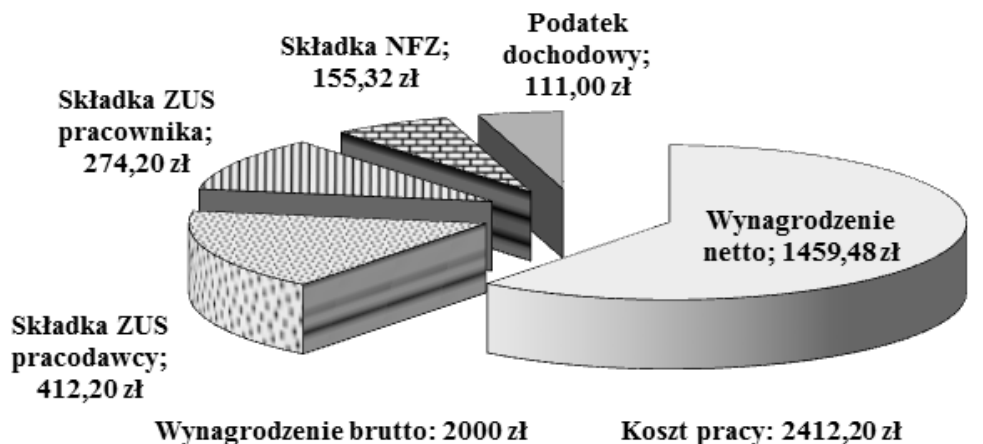

Klin podatkowy - 952,72 zł tj. 39,5\% kosztów pracy

Rysunek 3. Struktura kosztów pracy przy minimalnym wynagrodzeniu w Polsce w 2017 roku Źródło: opracowanie własne.

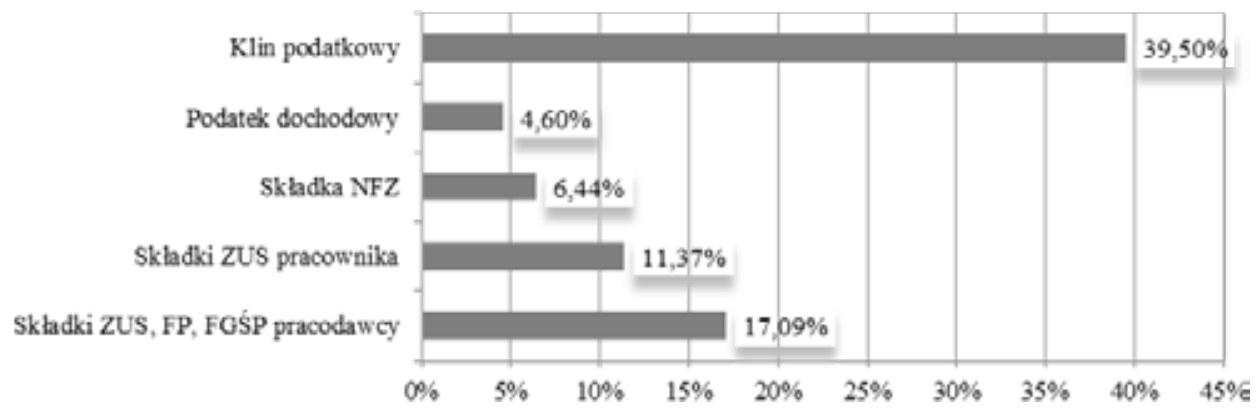

Rysunek 4. Struktura płacowego klina podatkowego przy minimalnym wynagrodzeniu w Polsce w 2017 roku

Źródło: opracowanie własne.

Rozpatrując strukturę płacowego klina podatkowego w Polsce można zauważyć, że różnica w jego wielkości uzależniona jest od wielkości dochodu, na co bezpośrednio wpływa wysokość ulgi zmniejszającej podatek dochodowy (kwoty wolnej od podatku). W przypadku przeciętnego wynagrodzenia klin podatkowy wyniósł 40,94\%, natomiast przy minimalnym 
wynagrodzeniu - 39,5\% całkowitych kosztów pracy, a więc różnica stanowi 1,44 p.p. Zmiany w strukturze dotyczą tylko podatku dochodowego, pozostałe elementy pozostają w strukturze bez zmian (por. rys. 2 i 4).

\section{Analiza kosztów pracy w wybranych krajach Unii Europejskiej}

Do analizy struktury kosztów pracy wybrano kraje Unii Europejskiej należące do OECD (Organizacja Współpracy Gospodarczej i Rozwoju), skupiającej wysokorozwinięte i demokratyczne państwa świata. Wśród 28 krajów Unii Europejskiej do grupy państw OECD zaliczanych jest 21 krajów, w tym Polska. Przedmiotem analizy będzie wysokość płacowego klina podatkowego (tax wedge), średnie stawki na ubezpieczenie społeczne płacone przez pracownika, średnie stawki na ubezpieczenie społeczne płacone przez pracodawcę oraz średnie stawki podatku dochodowego od wynagrodzeń. Podane stawki przedstawiono według metodologii ustalonej przez OECD.

Dokonując analizy struktury płacowego klina podatkowego w 21 krajach Unii Europejskiej w 2016 roku (por. tab. 1), można zwrócić uwagę na zróżnicowany poziom i strukturę płacowego klina podatkowego. Rozpiętość pomiędzy najwyższym (Belgia) a najniższym poziomem (Irlandia) klina podatkowego wśród badanych krajów wynosi 39,34 p.p. Najwyższy poziom płacowego klina podatkowego, stanowiącego ponad $65 \%$ całkowitych kosztów pracy uzyskały Belgia $(69,43 \%)$ i Francja (65,65\%). Najniższy poziom płacowego klina podatkowego poniżej 35\% odnotowały Irlandia (30\%) oraz Wielka Brytania (34,8\%).

Należy jednak zwrócić uwagę, że płacowy klin podatkowy wyrażony w procentach nie jest jedynym czynnikiem, który powinien być brany pod uwagę w analizie obciążeń podatkowych i parapodatkowych pracy. Duże znaczenie w kontekście porównań międzynarodowych ma przeciętny poziom wynagrodzenia, a więc koszty pracy wyrażone w ujęciu wartościowym. Biorąc pod uwagę przeciętne roczne koszty pracy w dolarach, według metodologii OECD, krajami o najniższych kosztach pracy są kraje „,nowej unii”‘: Słowacja, Polska, Węgry, Estonia i Czechy, zaś krajami o najwyższych kosztach pracy, biorąc pod uwagę przeciętne wynagrodzenie w 2016 roku, są Niemcy i Belgia (por. tab. 1).

Nie bez znaczenia pozostaje także struktura płacowego klina podatkowego. We wszystkich analizowanych krajach, z wyjątkiem Danii, największy udział w płacowym klinie podatkowym mają składki na ubezpieczenia społeczne. Przeciętny ich udział w kosztach pracy wynosi $34,94 \%$, w tym $11,88 \%$ płacony przez pracownika, a $23,06 \%$ płacony przez pracodawcę. Najwyższe składki na ubezpieczenia społeczne odprowadzane są we Francji (50,85\%) i na Węgrzech (47\%), natomiast najniższe w Danii (0,78\%) oraz Irlandii (14,75\%). Poziom podatku dochodowego w strukturze kosztów pracy jest największy i przekracza 25\% tylko w dwóch krajach - Danii (36,19\%) oraz Belgii (26,78\%), a najniższy jego poziom jest w Polsce $-7,18 \%$ (por. tab. 1). Reasumując, można stwierdzić, że struktura kosztów pracy jest zróżnicowana i uzależniona od polityki społecznej i gospodarczej danego kraju.

6 Kraje przed rozszerzeniem krajów członkowskich w UE w 2004 r. 


\section{Tabela 1}

Roczne koszty pracy i struktura płacowego klina podatkowego w 2016 roku w krajach Unii Europejskiej należących do OECD

\begin{tabular}{|c|c|c|c|c|c|}
\hline Kraj & $\begin{array}{l}\text { Średnia stawka } \\
\text { składek na } \\
\text { ubezpieczenie } \\
\text { społeczne } \\
\text { pracowników w \% }\end{array}$ & $\begin{array}{l}\text { Średnia stawka } \\
\text { składek na } \\
\text { ubezpieczenie } \\
\text { społeczne } \\
\text { pracodawców w \% }\end{array}$ & $\begin{array}{l}\text { Średnia stawka } \\
\text { podatku } \\
\text { dochodowego w \% }\end{array}$ & $\begin{array}{l}\text { Klin } \\
\text { podatkowy } \\
\text { w } \%\end{array}$ & $\begin{array}{l}\text { Średnie } \\
\text { roczne koszty } \\
\text { pracy } \\
\text { (w USD) }\end{array}$ \\
\hline Słowacja & 13,40 & 31,20 & 9,84 & 54,44 & 29981,22 \\
\hline Polska & 17,83 & 16,78 & 7,18 & 41,78 & 31930,88 \\
\hline Węgry & 18,50 & 28,50 & 15,00 & 62,00 & 32930,32 \\
\hline Estonia & 1,60 & 33,80 & 16,69 & 52,09 & 34172,70 \\
\hline Czechy & 11,00 & 34,00 & 12,57 & 57,57 & 34696,79 \\
\hline Słowenia & 22,10 & 16,10 & 11,33 & 49,53 & 36498,79 \\
\hline Portugalia & 11,00 & 23,75 & 16,57 & 51,32 & 37057,68 \\
\hline Grecja & 15,79 & 24,85 & 9,60 & 50,24 & $41 \quad 168,91$ \\
\hline Irlandia & 4,00 & 10,75 & 15,25 & 30,00 & 49546,70 \\
\hline Hiszpania & 6,35 & 29,90 & 15,03 & 51,28 & 52318,54 \\
\hline Włochy & 9,49 & 31,88 & 21,63 & 63,00 & 55609,04 \\
\hline Dania & 0,00 & 0,78 & 36,19 & 36,97 & 57758,78 \\
\hline $\begin{array}{l}\text { Wielka } \\
\text { Brytania }\end{array}$ & 9,36 & 10,74 & 13,98 & 34,08 & 58714,32 \\
\hline Finlandia & 8,78 & 23,07 & 22,01 & 53,86 & 59663,03 \\
\hline Szwecja & 7,00 & 31,42 & 17,86 & 56,27 & 62358,67 \\
\hline Francja & 14,30 & 36,55 & 14,80 & 65,65 & 65293,98 \\
\hline Holandia & 13,54 & 11,20 & 16,90 & 41,65 & 70665,11 \\
\hline Austria & 17,98 & 28,91 & 13,89 & 60,78 & 71775,78 \\
\hline Luksemburg & 12,81 & 12,16 & 18,15 & 43,12 & 73489,31 \\
\hline Niemcy & 20,68 & 19,33 & 18,98 & 58,98 & 73683,07 \\
\hline Belgia & 13,97 & 28,69 & 26,78 & 69,43 & 74912,77 \\
\hline Przeciętnie & 11,88 & 23,06 & 16,68 & 51,62 & 52582,21 \\
\hline
\end{tabular}

Źródło: opracowanie własne na podstawie danych OECD.

Rozpatrując zmiany wielkości płacowego klina podatkowego (por. rys. 5), można zauważyć, że największej obniżki, biorąc pod uwagę lata 2010-2015, dokonały Holandia (1,9 p.p.) i Wielka Brytania (1,8 p.p.), natomiast największy wzrost płacowego klina podatkowego nastąpił w Luksemburgu (4 p.p.) oraz Portugalii (4,9 p.p.). 


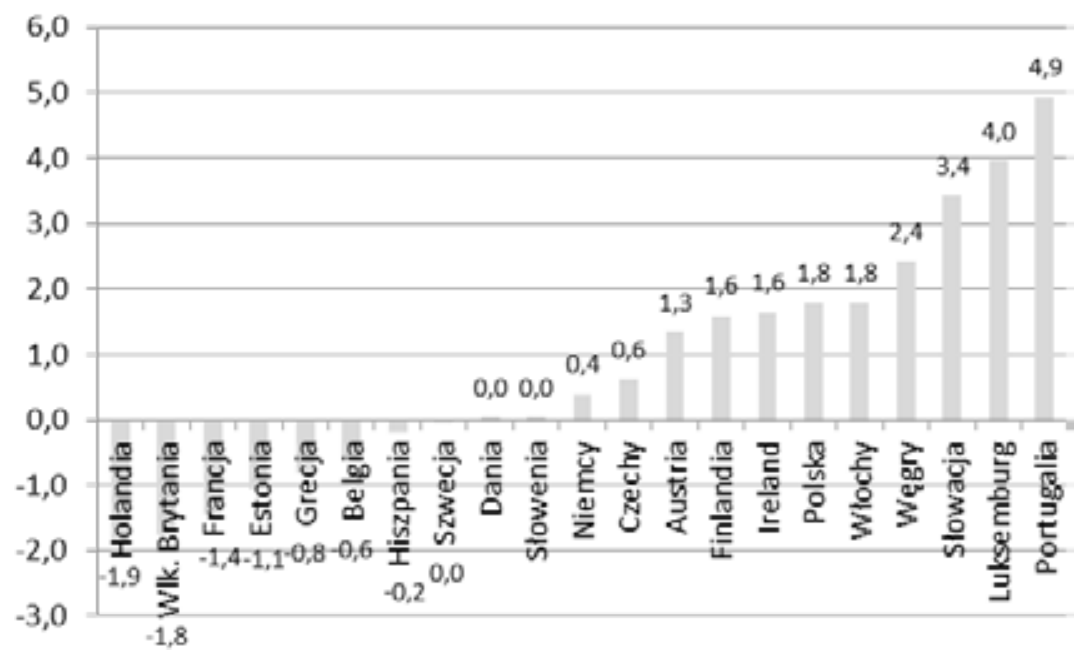

Rysunek 5. Zmiany klina podatkowego przy przeciętnym wynagrodzeniu w latach 2015/2010 w krajach Unii Europejskiej należących do OECD (w p.p.)

Źródło: opracowanie własne na podstawie danych OECD.

13 z 21 krajów UE należących do OECD dokonało podwyżki płacowego klina podatkowego. Może to wynikać przede wszystkim z sytuacji ekonomicznej danego kraju, nie bez znaczenia są także niekorzystne zjawiska demograficzne związane ze starzeniem się społeczeństwa w krajach Unii Europejskiej, co pociąga za sobą coraz wyższe koszty zabezpieczenia społecznego spoczywające na państwach. Znaczne zmiany poziomu płacowego klina podatkowego w poszczególnych krajach zależą od zmian poszczególnych składników wchodzących w skład kosztów pracy, a więc obniżce bądź podwyżce poszczególnych składek ubezpieczeniowych bądź podatku dochodowego. Należy wziąć pod uwagę, że zmiany poziomu klina podatkowego wpływają na wysokość dochodów publicznych i wielkość deficytu budżetowego.

Dla porównania warto zwrócić uwagę także na poziom minimalnego wynagrodzenia w poszczególnych krajach Unii Europejskiej (por. tab. 2).

22 kraje Unii Europejskiej mają ustalony minimalny poziom wynagrodzenia. Najniższe minimalne wynagrodzenie jest w krajach „nowej unii”, w których m.in. Bułgaria, Rumunia, Lotwa i Litwa, ma minimalny poziom wynagrodzenia nieprzekraczający 400 euro miesięcznie, a w Bułgarii kształtuje się na poziomie 235,62 euro miesięcznie. Najwyższy poziom minimalnego wynagrodzenia mają kraje „starej unii”, tj. Belgia, Holandia, Irlandia i Luksemburg, gdzie przekracza on poziom 1500 euro miesięcznie, a w Luksemburgu osiąga poziom 1998,59 euro miesięcznie. Powyższe dane stanowią jeden z elementów decyzyjności inwestorów w zakresie lokowania inwestycji zagranicznych, gdyż element kosztów pracy stanowi ważny czynnik opłacalności inwestycji. 


\section{Tabela 2}

Minimalne wynagrodzenie brutto w 2017 r. w krajach Unii Europejskiej

\begin{tabular}{llll}
\hline Kraj & Wynagrodzenie w euro & Rodzaj stawki & $\begin{array}{l}\text { Wynagrodzenie miesięczne } \\
\text { w euro }\end{array}$ \\
\hline Bułgaria & 235,62 & miesięczna & 235,62 \\
\hline Rumunia & 321,17 & miesięczna & 321,17 \\
\hline Łotwa & 380,00 & miesięczna & 380,00 \\
\hline Litwa & 380,00 & miesięczna & 380,00 \\
\hline Czechy & 407,64 & miesięczna & 407,64 \\
\hline Węgry & 412,91 & miesięczna & 412,91 \\
\hline Słowacja & 435,00 & miesięczna & 435,00 \\
\hline Chorwacja & 436,91 & miesięczna & 436,91 \\
\hline Polska & 454,52 & miesięczna & 454,52 \\
\hline Estonia & 470,00 & miesięczna & 470,00 \\
\hline Portugalia & 557,00 & miesięczna & 557,00 \\
\hline Grecja & 586,08 & miesięczna & 586,08 \\
\hline Malta & 169,76 & tygodniowe & 679,04 \\
\hline Hiszpania & 707,60 & miesięczna & 707,60 \\
\hline Stowenia & 804,96 & miesięczna & 804,96 \\
\hline Wielka Brytania & 8,80 & godzinowa & 1478,40 \\
\hline Francja & 1480,27 & miesięczna & 1480,27 \\
\hline Niemcy & 8,84 & godzinowa & 1485,12 \\
\hline Belgia & 1531,93 & miesięczna & 1531,93 \\
\hline Holandia & 1551,60 & miesięczna & 1551,60 \\
\hline Irlandia & 9,25 & godzinowe & 1554,00 \\
\hline Luksemburg & 1998,59 & miesięczna & 1998,59 \\
\hline & & Era & \\
\hline
\end{tabular}

Źródło: opracowanie własne na podstawie danych: (Eurofound, 2017), (Statutory minimum wages in the EU 2017).

\section{Uwagi końcowe}

Struktura kosztów pracy jest zróżnicowana w poszczególnych krajach Unii Europejskiej. Uzależniona jest przede wszystkim od systemu ubezpieczeń społecznych danego kraju i związanym z nim wysokością obowiązkowych składek ubezpieczeniowych, a także od poziomu i konstrukcji podatku dochodowego. Z przeprowadzonych analiz wynika, że składki na ubezpieczenia społeczne stanowią największą część w strukturze kosztów pracy. Nie bez znaczenia w tym zakresie pozostaje porównanie poziomu minimalnego i przeciętnego wynagrodzenia w gospodarce narodowej. Biorąc pod uwagę elementy składające się na strukturę 
kosztów pracy, można rozpatrywać je w kilku aspektach, tj. z punktu widzenia finansów przedsiębiorstwa, finansów publicznych, finansów osobistych (gospodarstw domowych) jak i finansów międzynarodowych. Dla przedsiębiorstw rodzimych i inwestorów zagranicznych podstawową informacją będą całkowite koszty pracy, dla gospodarstwa domowego istotna będzie kwestia otrzymywanego wynagrodzenia netto, a dla państwa - jak najwyższy udział obciążeń publicznych w strukturze kosztów pracy, co przekłada się na maksymalizację dochodów budżetowych.

\title{
Literatura
}

Eurofound (2017). Statutory minimum wages in the EU 2017. Dublin.

Eurostat (2017). Pobrane z: http://ec.europa.eu/eurostat/statistics-explained/index.php.

Furmańska-Maruszak, A. (2013). Racjonalizacja kosztów pracy przez uelastycznienie zatrudnienia i czasu pracy.

Szanse i zagrożenia dla małych i średnich przedsiębiorstw. Zarządzanie Zasobami Ludzkimi, 3/4.

Koszty pracy w gospodarce narodowej w 2012 (2013). Warszawa: GUS.

Labour taxes and employement in the EU-8 (2005). World Bank EU-8: Quarterly Economic Report.

Makowski, K. (2000). Koszty pracy - instrument zarzadzania. Warszawa: Poltext.

OECD (2017). Explanatory notes to the OECD databases. Taxing Wages 2017.

Polarczyk, K. (2007). Klin podatkowy a bezrobocie. Warszawa: Biuro Analiz Sejmowych: Infos nr 17.

Triplett, J.E. (1983). The Measurement of Labor Cost. Chicago: National Bureau of Economic Reasearch.

Ustawa z dnia 13 października 1998 r. o systemie ubezpieczeń społecznych (Dz.U. z 2008 r., nr 171, poz. 1056).

Ustawa z dnia 20 kwietnia 2004 r. o promocji zatrudnienia i instytucjach rynku pracy (Dz.U. z 2008 r., nr 69, poz. 415 z późn. zm.).

Ustawa z dnia 26 lipca 1991 r. o podatku dochodowym od osób fizycznych (Dz.U. z 2000 r., nr 14, poz. 176 z późn. zm.).

Ustawa z dnia 29 grudnia 1993 r. o ochronie roszczeń pracowniczych w razie niewypłacalności pracodawcy (Dz.U. z 1994 r., nr 1, poz.1, z późn. zm.).

Ustawa z dnia 6 lutego 1997 r. o powszechnym ubezpieczeniu zdrowotnym (Dz.U. z 1997 r., nr 28, poz. 153 z późn. $z m$.).

\section{THE STRUCTURE OF LABOR COSTS IN THE SELECTED EU COUNTRIES}

\begin{abstract}
Purpose - Analysis of the labor costs structure in the selected EU countries and the possibility of their equivalence between countries.

Design/Methodology/approach - The introductory part was used by the analysis of literature and legal acts, while the empirical part used the method of examining documents based on official OECD reports and author calculations.

Findings - Analysis of the labor cost structure in selected EU countries showed that it varies in different European Union countries and depends on the socio-economic policy of the country, i.e. the social security system and the level and structure of income tax.

Originality/value - When analyzing labor costs, it is important to pay attention first to the minimum and average levels of wages and the level of non-wage costs in the individual countries, because they mainly determine the real cost of work charged by the employer.
\end{abstract}

Keywords: labor costs, tax wedge, European Union

\section{Cytowanie}

Rosiński, R. (2017). Struktura kosztów pracy w wybranych krajach Unii Europejskiej. Finanse, Rynki Finansowe,

Ubezpieczenia, 3 (87/2), 151-160. DOI: 10.18276/frfu.2017.87/2-13. 